\title{
New Sources of Temperature-Sensitive Resistance to Wheat streak mosaic virus in Wheat
}

Dallas L. Seifers, Professor, Kansas State University, Agricultural Research Center-Hays 67601; Steve Haber, Cereal Research Centre, Agriculture \& Agri-Food Canada, Winnipeg, Manitoba, Canada; and T. J. Martin, Professor, and Guorong Zhang, Assistant Professor, Kansas State University, Agricultural Research Center-Hays \begin{abstract}
Plant Dis. 97:1051-1056.
Expressing temperature-sensitive resistance (TSR) protects wheat against yield losses from infection with Wheat streak mosaic virus (WSMV). In examining how 2,429 wheat accessions from the National Small Grains Collection responded to inoculation with the Sid81 isolate of WSMV, 20 candidate TSR sources were discovered. To differentiate their relative effectiveness, accession responses over 21 days to inoculation with GH95, Sid81, and PV57 virus isolates in regimes of 18 and $20^{\circ} \mathrm{C}$ were observed. At $18^{\circ} \mathrm{C}$, all 20 candidate TSR sources were uniformly or nearly uniformly asymptomatic 21 days after inoculation with the PV57 isolate, resistance indistinguishable from resistant checks KS96HW10-3 and RonL. By contrast, the Sid81 isolate
\end{abstract}

Abstract

Seifers, D. L., Haber, S., Martin, T. J., and Zhang, G. 2013. New sources of temperature-sensitive resistance to Wheat streak mosaic virus in wheat.

induced symptoms in low but significant proportions of plants of two candidates, and the GH95 isolate in high proportions for four candidates and low but significant proportions for two others. In the more stringent $20^{\circ} \mathrm{C}$ regime, the uniform or near-uniform induction of symptoms in response to inoculation with GH95 failed to differentiate among the 20 candidate TSR sources and two resistant checks, while PV57 and Sid81 identified several candidates that performed similarly to KS96HW10-3 and significantly better than RonL. By identifying new sources of resistance, this study contributes to the control of WSMV.
Wheat streak mosaic virus (WSMV), the causal agent of wheat streak mosaic (WSM), is designated as the type member of the genus Tritimovirus in the family Potyviridae (30). In Kansas, WSM can reduce the statewide value of wheat crops by as much as $13 \%$ $(13,28,32)$ and, in other areas of the Great Plains, losses of 32 to $96 \%$ have been reported (2). There are two broad general strategies available to control WSM. One is to interrupt transmission and the other is to enhance the host's ability to tolerate or resist the virus infection itself.

The virus is naturally transmitted by the wheat curl mite (WCM), Aceria tosichella Keifer (29), which is also capable of transmitting the High Plains virus (23) and Triticum mosaic virus (24). Two genetically distinct lineages of A. tosichella have recently been identified in Australia, one of which fails to transmit WSMV in laboratory trials (21). Imparting genetic resistance to WCM would protect wheat against several distinct viruses at the same time, and control has been obtained by introgressing one or more sources of genetic resistance to WCM feeding from an array of species related to wheat (10). However, the ability of mite vector populations to evolve rapidly from avirulence to virulence limits the cost effectiveness of this approach for breeding programs aiming to control losses from WSM (10).

Seed transmission of WSMV in wheat has been documented $(1,11,12)$. Although this must be considered as a risk for accidentally introducing the virus into hitherto virus-free regions (12), control of seed transmission likely plays no role in reducing losses in areas where the virus and its vector are already established.

Corresponding author: D. L. Seifers, E-mail: dseifers@ksu.edu

This research has been assigned contribution number 13-163-J from the Kansas Agricultural Experiment Station.

Accepted for publication 6 February 2013.

http://dx.doi.org/10.1094/PDIS-11-12-1029-RE

(C) 2013 The American Phytopathological Society
The control of losses from WSM by enhancing host genetic resistance to the virus itself is a goal that has been pursued since natural resistance to WSMV infection was first discovered in wild relatives of wheat (19). Host resistance which prevents systemic infection and expression of symptoms has now been identified in a diverse array of wheat lines, both in lines in which resistance is associated with alien chromatin (25) and in lines derived entirely from wheat germplasm $(4,7,26,27)$. When tested in regimes of controlled temperature, the expression of resistance can be observed to be sensitive to temperature, and different resistance sources may be distinguished by the temperature threshold at which the expression of resistance is abolished $(3,4)$. Several temperaturesensitive resistance (TSR) sources express complete resistance at $18^{\circ} \mathrm{C}$ but permit systemic infection and symptoms when exposed to higher temperatures for sustained periods $(3,4,9,25-27)$.

Several genetic sources of WSMV resistance in wheat have become sufficiently characterized to be given named designations. Resistance deriving from chromosome 4 of Thinopyrum intermedium is designated as Wsml (5). This gene has been deployed as a chromosome translocation in the experimental line KS96HW10-3 (25) and the recently released 'Mace' (6), where it expresses TSR.

In an advanced breeding line, CO960293 $(9,15,27)$, which was derived entirely from susceptible pedigree wheat parents (27), a TSR was identified and subsequently deployed in 'RonL' (27) and 'Snowmass' (8). The susceptibility of all its pedigree parents precludes a simple tracing of this TSR, now designated Wsm2 $(16,17)$, to a discrete Mendelian source. However, Wsm2 has recently been shown to be tightly linked to a simple-sequence repeat DNA marker on the short arm of chromosome 3B (17) in mapping populations derived from crosses of CO960293 with the susceptible 'TAM111' and 'Yuma' (17). A second source of TSR was identified from the line CO960333 (D. L. Seifers, unpublished). As with $\mathrm{C} 0960293$, the resistance expressed in $\mathrm{CO} 960333$ at $18^{\circ} \mathrm{C}$ when inoculated with the Sid81 isolate of WSMV is not expressed in any of the pedigree parents of this line (D. L. Seifers, unpublished). An additional source of resistance was identified in KS03HW-12 but the gene for resistance has not been identified (26).

A source of WSMV resistance, designated Wsm3, has recently been identified in the experimental wheat line KS12WGGRC59 
with a translocation from $T$. intermedium chromosome arm 7S\#3L (15). Wsm 3 confers resistance to WSMV at sustained temperatures as high as $24^{\circ} \mathrm{C}$ and to Triticum mosaic virus (TriMV) at 18 but not $24^{\circ} \mathrm{C}$.

The TSRs expressed in Wsml-bearing KS96HW10-3, Wsm2bearing CO960293, KS03HW12, and CO960333 protected against significant yield losses in replicated field trials in Kansas mechanically inoculated with the Sid81 isolate of WSMV (25-27; D. L. Seifers, unpublished).

If TSR can be found that is heritably expressed in sublines descended from the progeny of susceptible parents, as appears to have occurred with CO960293 (27), the question arises of whether TSR might similarly be discovered in sublines descended by selfing from a true-breeding single progenitor. Such a TSR was observed among a subset of individuals of the WSMV-susceptible doubled-haploid (DH) spring wheat experimental line C2652, and repeated rounds of iterative selection under pressure from inoculation with WSMV yielded the uniformly resistant subline 'c2652' (4). In greenhouse and field trials in Australia, this resistance prevented expression of symptoms and protected against yield losses at temperatures as high as $28^{\circ} \mathrm{C}(3,4)$. The hypothesis that TSR could be evolved de novo in generations directly descended from a susceptible progenitor was strengthened by showing that a single seed of the Canadian DH spring wheat 'McKenzie' could yield, under carefully controlled conditions, descendant selfed sublines that expressed TSR to inoculation with WSMV (7). One of these sublines, provisionally named 'Hume', expressed a TSR that was effective at $21^{\circ} \mathrm{C}$ (7) but abolished at $24^{\circ} \mathrm{C}$ (D. L. Seifers, unpublished). Hume's TSR was inherited in the $\mathrm{F}_{1}$ and $\mathrm{F}_{2}$ progeny of McKenzie $\times$ Hume crosses in a manner consistent with the action a single dominant gene (7).

The above examples suggest that genes for TSR in wheat might not be rare but remain unexpressed in most pedigree-bred wheat lines. Thus, a wide array of wheat lines should be examined to identify a subset in which a detectable proportion of individuals expressed TSR to inoculation with WSMV. Our initial screen of 2,429 accessions from the National Small Grains Collection using the Sid81 isolate of WSMV in a temperature regime of $18^{\circ} \mathrm{C}$ identified 20 candidates for further TSR characterization. We report here how these lines responded to inoculation with three distinct isolates of WSMV in growth chamber regimes of 18 and $20^{\circ} \mathrm{C}$ in order to identify new TSR sources that may prove of value to wheat improvement programs.

\section{Materials and Methods}

Virus sources and maintenance. The GH95, Sid81, and PV57 isolates of WSMV (Table 1), which represent different clades based on coat protein polymorphism (31), were used in this study. These virus isolates were chosen because of the response of RonL wheat plants following mechanical inoculation with these isolates when held at $18^{\circ} \mathrm{C}$ (D. L. Seifers, unpublished). The virus isolates were increased in 'Tomahawk' wheat in a growth chamber (Percival Model PGC-15 WC) set a $22^{\circ} \mathrm{C}$ with a 12 -h photoperiod under fluorescent light $\left(250 \mu \mathrm{Es}^{-1} \mathrm{~m}^{-2}\right)$ by planting seed in small metal soil-filled (Harney clay loam soil, fine montmorillonitic, mesic type Argiustoll) flats $(21$ by $31 \mathrm{~cm})$. Once plants were at the single-leaf stage of development, they were then mechanically (finger rub) inoculated with 1:10 (wt/vol) extracts of the appropriate virus isolate. Inoculated plants were maintained in the growth chamber under the same light and temperature conditions for 14 days.

Table 1. Wheat streak mosaic virus isolates used to screen wheat lines

\begin{tabular}{llccc}
\hline Isolate & $\begin{array}{c}\text { Geographic } \\
\text { origin }\end{array}$ & $\begin{array}{c}\text { Year } \\
\text { isolated }\end{array}$ & Host & Clade $^{\mathbf{z}}$ \\
\hline PV57 & Kansas & 1932 & Wheat & D2 \\
GH95 & Kansas & 1995 & Wheat & D3 \\
Sid81 & Nebraska & 1981 & Wheat & D4 \\
\hline
\end{tabular}

${ }^{\mathrm{z}}$ Isolates assigned to clades based on comparison of consensus sequences of the coat proteins (31).
Symptomatic plants were then harvested separately for each isolate and 1-g samples (four to six plants per sample) prepared and immediately frozen at $-80^{\circ} \mathrm{C}$, prior to the start of the study.

Source of wheat germplasm and screening procedures. The 2,429 accessions screened for resistance to WSMV in this study were obtained from the United States Department of AgricultureAgricultural Research Service, National Small Grains Research Facility, Aberdeen, ID. The seed of the accessions were planted into 30 by $50-\mathrm{cm}$ soil-filled (as described above) metal flats at 10 seeds/row for each entry in a completely randomized design. Plants were mechanically inoculated (22) with the Sid81 isolate of WSMV at the single-leaf stage and held at $18^{\circ} \mathrm{C}$ in a growth chamber (Percival Model PGC-15 WC) with illumination $\left(250 \mu \mathrm{Es}^{-1} \mathrm{~m}^{-2}\right)$ at $10 \mathrm{~h} /$ day. Plants were then rated for the presence of systemic symptoms 14 days following inoculation (14 DPI). Because of the large numbers of accessions, only lines whose plants were uniformly free of symptoms at $14 \mathrm{DPI}$ in the first experiment were again inoculated in a second experiment to verify that plants of those lines were again symptomless. Lines whose plants were uniformly free of symptoms in both experiments were identified as candidate TSR lines (Table 2). Individual inoculated plants of these lines were then transplanted to pots and vernalized at 5 to $6^{\circ} \mathrm{C}$ in a growth chamber for 7 weeks, followed by growth to maturity in a greenhouse under natural lighting. Plants of the candidate TSR lines which had been selected at $18^{\circ} \mathrm{C}$ before vernalization uniformly developed symptoms as they grew post vernalization to maturity in the warmer greenhouse temperatures (not recorded). Seed were collected from a plant of each candidate TSR line and later planted in separate rows in the ground for increase in a greenhouse. The seed from the plants in these rows of candidate TSR lines were each harvested separately and bulked from that row. These seed sources were then used to evaluate responses to inoculation with the three WSMV isolates in the 18 and $20^{\circ} \mathrm{C}$ phenotyping regimes.

Phenotyping wheat accessions with WSMV. Seed from the 20 candidate TSR lines identified in the initial screening with WSMV (Table 2) were planted in separate rows in a soil-filled (Harney clay loam soil, fine montmorillonitic, mesic type Argiustoll) flats (30 by $50 \mathrm{~cm}$ ) with 14 rows, each divided in half, so that 28 rows were made, of which 20 were planted with the candidate TSR lines; 2 rows with seed of KS96HW10-3 and RonL, each with TSR to WSMV (25,27); and 1 row of 'T81', the susceptible control (D. L. Seifers, unpublished), in a randomized complete block design. This was done for 12 flats, so that 2 flats of wheat accessions were available to be inoculated with each isolate. The flats of wheat plants were held in growth chambers (Percival Model PGC-15

Table 2. Wheat lines selected from the National Small Grains Collection expressing uniform, temperature-sensitive resistance to Sid81 isolate of Wheat streak mosaic virus

\begin{tabular}{lll}
\hline Identification number & Habit & Country \\
\hline CItr9358 & Winter & Finland \\
PI225220 & Winter & Iran \\
PI225222 & Winter & Iran \\
PI225288 & Winter & Iran \\
PI243652 & Winter & Iran \\
PI243753 & Winter & Iran \\
PI245399 & Winter & Afghanistan \\
PI245439 & Facultative & Afghanistan \\
PI245526 & Facultative & Afghanistan \\
PI268438 & Winter & Afghanistan \\
PI268459 & Winter & Afghanistan \\
PI321730 & Winter & Afghanistan \\
PI243635 & Spring & Iran \\
PI243669 & Spring & Iran \\
PI245539 & Spring & Afghanistan \\
PI250041 & Spring & Iran \\
PI342631 & Spring & Iran \\
PI366549 & Spring & Afghanistan \\
PI367127 & Spring & Afghanistan \\
PI478095 & Facultative & Pakistan \\
\hline
\end{tabular}


WC) set a $21^{\circ} \mathrm{C}$ with a 12 -h photoperiod under fluorescent light $\left(250 \mu \mathrm{Es}^{-1} \mathrm{~m}^{-2}\right)$. Plants at the single-leaf stage were mechanically (finger rub) inoculated with 1:10 (wt/vol) extract of the appropriate virus isolate, so that two flats, each having all candidate TSR lines and controls, were inoculated with each virus isolate. Following inoculation, the temperature was set to $18^{\circ} \mathrm{C}$ in one growth chamber and $20^{\circ} \mathrm{C}$ in the other. The inoculated plants were rated for systemic symptoms at 7,14, and 21 DPI. The experiment was conducted three times and each was considered as a replication-intime in the analysis of variance (ANOVA). Infectivity data were recorded as percentages. As differences among treatments exceeded 40 percentage points (14), the data were arcsine-transformed before conducting the ANOVA. The infectivity data presented in the tables are untransformed. ANOVA was conducted using SAS (version 8; SAS Institute) and significant treatment effects were determined using Fisher's protected least significant difference $(P=0.05)$.

\section{Results}

We mechanically inoculated 2,429 accessions from the National Small Grains Collection with the Sidney 81 isolate of WSMV, and 20 of the accessions were considered as candidate sources of resistance (Table 2). These accessions were from Afghanistan, Finland, Iran, and Pakistan. From Afghanistan, 9 of 1,465 accessions were resistant; from Finland, 1 of 72; from Iran, 9 of 627; and from Pakistan, 1 of 265.

In the $18^{\circ} \mathrm{C}$ regime at $7 \mathrm{DPI}$, the 20 candidate TSR sources remained uniformly free of symptoms at 7 DPI, whereas plants of the T81 susceptible check uniformly displayed symptoms (data not shown). At 7 DPI in the $20^{\circ} \mathrm{C}$ regime, the susceptible check was uniformly infected, the Wsml-bearing resistant check KS86HW103 was uniformly symptom free, and the Wsm2-bearing resistant check RonL showed a differentiated response with 9, 10, and $83 \%$ symptomatic plants after inoculation with the PV57, Sid81, and

Table 3. Percentages of symptomatic wheat plants for different wheat lines in response to mechanical inoculation with three isolates of Wheat streak mosaic virus (WSMV) after 7 days at $20^{\circ} \mathrm{C}^{\mathrm{y}}$

\begin{tabular}{lccc}
\hline & \multicolumn{3}{c}{ WSMV isolate $^{\mathbf{z}}$} \\
\cline { 2 - 4 } Identification number & GH95 & Sid81 & PV57 \\
\hline CItr9358 & $16 \mathrm{de}$ & $0 \mathrm{~g}$ & $5 \mathrm{fg}$ \\
PI225220 & $43 \mathrm{c}$ & $0 \mathrm{~g}$ & $0 \mathrm{~g}$ \\
PI225222 & $5 \mathrm{fg}$ & $0 \mathrm{~g}$ & $5 \mathrm{fg}$ \\
PI225288 & $4 \mathrm{fg}$ & $0 \mathrm{~g}$ & $0 \mathrm{~g}$ \\
PI243652 & $0 \mathrm{~g}$ & $0 \mathrm{~g}$ & $0 \mathrm{~g}$ \\
PI243753 & $0 \mathrm{~g}$ & $0 \mathrm{~g}$ & $0 \mathrm{~g}$ \\
PI245399 & $4 \mathrm{fg}$ & $0 \mathrm{~g}$ & $0 \mathrm{~g}$ \\
PI245439 & $0 \mathrm{~g}$ & $0 \mathrm{~g}$ & $0 \mathrm{~g}$ \\
PI245526 & $9 \mathrm{ef}$ & $0 \mathrm{~g}$ & $0 \mathrm{~g}$ \\
PI268438 & $8 \mathrm{fg}$ & $0 \mathrm{~g}$ & $0 \mathrm{~g}$ \\
PI268459 & $12 \mathrm{de}$ & $0 \mathrm{~g}$ & $0 \mathrm{~g}$ \\
PI321730 & $0 \mathrm{~g}$ & $0 \mathrm{~g}$ & $0 \mathrm{~g}$ \\
PI243639 & $0 \mathrm{~g}$ & $0 \mathrm{~g}$ & $0 \mathrm{~g}$ \\
PI243669 & $0 \mathrm{~g}$ & $0 \mathrm{~g}$ & $0 \mathrm{~g}$ \\
PI245539 & $0 \mathrm{~g}$ & $0 \mathrm{~g}$ & $0 \mathrm{~g}$ \\
PI250041 & $0 \mathrm{~g}$ & $0 \mathrm{~g}$ & $0 \mathrm{~g}$ \\
PI342631 & $4 \mathrm{fg}$ & $0 \mathrm{~g}$ & $0 \mathrm{~g}$ \\
PI366549 & $0 \mathrm{~g}$ & $0 \mathrm{~g}$ & $0 \mathrm{~g}$ \\
PI367127 & $96 \mathrm{a}$ & $30 \mathrm{~d}$ & $4 \mathrm{fg}$ \\
PI478095 & $4 \mathrm{fg}$ & $0 \mathrm{~g}$ & $0 \mathrm{~g}$ \\
RonL & $83 \mathrm{~b}$ & $10 \mathrm{ef}$ & $9 \mathrm{ef}$ \\
KS96HW10-3 & $0 \mathrm{~g}$ & $0 \mathrm{~g}$ & $0 \mathrm{~g}$ \\
T81 & $100 \mathrm{a}$ & $100 \mathrm{a}$ & $100 \mathrm{a}$ \\
Overall mean & 16.9 & 6.1 & 5.3 \\
\hline
\end{tabular}

${ }^{\mathrm{y}}$ Percentages are means from three experiments and are not arcsine transformed. However, values were arcsine transformed prior to analyses. Total plant numbers of plants for a given accession and virus isolate were 19 to 24 .

${ }^{\mathrm{y}}$ Treatments not having the same letter (within and across columns) in common are significantly different using Fisher's protected least significance difference $(P=0.05)$. The probability associated with the $F$ value was $<0.0001$.
GH95 isolates, respectively (Table 3). Among the 20 candidate TSR sources, 9 remained uniformly free of symptoms at 7 DPI in the $20^{\circ} \mathrm{C}$ regime (Table 3 ). For the other 11 candidates, inoculation with the GH95 isolate resulted in the highest proportions of symptomatic plants (Table 3). In the set of PI367127 plants, 96\% displayed systemic symptoms, a value not significantly different from that of the susceptible T81 control but different from values for all other TSR candidates inoculated with the GH95 isolate. All TSR candidates inoculated with the Sid81 isolate were uniformly symptom-free except for PI367127. The PV57 isolate induced symptoms in plants of only three TSR candidates: CItr9358, PI225222, and PI367127. Their low proportions of symptomatic plants were not significantly different from the complete absence of symptoms induced in the Wsm1-bearing resistant check KS96HW10-3 and all the other TSR candidates, and were similar to the low proportions observed for the Wsm2-bearing resistant check RonL (Table 3). The overall infection means for the GH95, Sid81, and PV57 isolates after 7 days at $18^{\circ} \mathrm{C}$ were $16.9,6.1$, and $5.3 \%$, respectively.

In the $18^{\circ} \mathrm{C}$ regime, the rate at which proportions of symptomatic plants increased from 7 to 21 DPI differentiated the relative virulence of the three WSMV isolates and the relative strength of resistance expressed among the 20 candidate TSR sources (Tables 4 and 5). For the T81 susceptible control, all three WSMV isolates induced uniformly symptomatic responses from 7 DPI onward. The TSR expressed by the Wsml-bearing resistant check KS86HW10-3 was almost completely effective over the 21-day period against all three isolates, the small proportion of symptomatic plants at 21 DPI in response to inoculation with the Sid81 isolate being statistically indistinguishable from the uniformly asymptomatic response of 8 of the 20 candidate TSR sources (Table 5). The TSR expressed by the Wsm2-bearing resistant check RonL was likewise almost completely effective over the 21-day period against all three isolates but, from 14 DPI on, a small proportion of inoculated plants showed symptoms in response to inoc-

Table 4. Percentages of symptomatic wheat plants for different wheat lines in response to mechanical inoculation with three isolates of Wheat streak mosaic virus (WSMV) after 14 days at $18^{\circ} \mathrm{C}^{\mathrm{y}}$

\begin{tabular}{lccc}
\hline & \multicolumn{3}{c}{ WSMV isolate } \\
\cline { 2 - 4 } Identification number & GH95 & Sid81 & PV57 \\
\hline CItr9358 & $0 \mathrm{~d}$ & $0 \mathrm{~d}$ & $0 \mathrm{~d}$ \\
PI225220 & $15 \mathrm{bc}$ & $0 \mathrm{~d}$ & $0 \mathrm{~d}$ \\
PI225222 & $0 \mathrm{~d}$ & $0 \mathrm{~d}$ & $0 \mathrm{~d}$ \\
PI225288 & $0 \mathrm{~d}$ & $0 \mathrm{~d}$ & $0 \mathrm{~d}$ \\
PI243652 & $0 \mathrm{~d}$ & $5 \mathrm{~cd}$ & $0 \mathrm{~d}$ \\
PI243753 & $0 \mathrm{~d}$ & $0 \mathrm{~d}$ & $0 \mathrm{~d}$ \\
PI245399 & $0 \mathrm{~d}$ & $0 \mathrm{~d}$ & $0 \mathrm{~d}$ \\
PI245439 & $4 \mathrm{~cd}$ & $0 \mathrm{~d}$ & $0 \mathrm{~d}$ \\
PI245526 & $0 \mathrm{~d}$ & $0 \mathrm{~d}$ & $0 \mathrm{~d}$ \\
PI268438 & $8 \mathrm{~cd}$ & $0 \mathrm{~d}$ & $4 \mathrm{~cd}$ \\
PI268459 & $8 \mathrm{~cd}$ & $0 \mathrm{~d}$ & $0 \mathrm{~d}$ \\
PI321730 & $0 \mathrm{~d}$ & $0 \mathrm{~d}$ & $0 \mathrm{~d}$ \\
PI243639 & $0 \mathrm{~d}$ & $0 \mathrm{~d}$ & $0 \mathrm{~d}$ \\
PI243669 & $0 \mathrm{~d}$ & $0 \mathrm{~d}$ & $0 \mathrm{~d}$ \\
PI245539 & $0 \mathrm{~d}$ & $0 \mathrm{~d}$ & $0 \mathrm{~d}$ \\
PI250041 & $0 \mathrm{~d}$ & $0 \mathrm{~d}$ & $0 \mathrm{~d}$ \\
PI342631 & $0 \mathrm{~d}$ & $0 \mathrm{~d}$ & $0 \mathrm{~d}$ \\
PI366549 & $0 \mathrm{~d}$ & $0 \mathrm{~d}$ & $0 \mathrm{~d}$ \\
PI367127 & $26 \mathrm{~b}$ & $0 \mathrm{~d}$ & $0 \mathrm{~d}$ \\
PI478095 & $0 \mathrm{~d}$ & $0 \mathrm{~d}$ & $0 \mathrm{~d}$ \\
RonL & $4 \mathrm{~cd}$ & $0 \mathrm{~d}$ & $0 \mathrm{~d}$ \\
KS96HW10-3 & $0 \mathrm{~d}$ & $0 \mathrm{~d}$ & $0 \mathrm{~d}$ \\
T81 & 7.1 & 4.6 & $\mathrm{a}$ \\
Overall mean & $0 \mathrm{a}$ & a & \\
\hline
\end{tabular}

y Percentages are means from three experiments and are not arcsine transformed. However, values were arcsine transformed prior to analyses. Total plant numbers of plants for a given accession and virus isolate were 18 to 26 .

z Treatments not having the same letter (within and across columns) in common are significantly different using Fisher's protected least significance difference $(P=0.05)$. The probability associated with the $F$ value was $<0.0001$. 
ulation with the GH95 isolate, a response statistically indistinguishable from the uniformly asymptomatic response of 8 of the 20 candidate TSR sources (Tables 4 and 5). The overall infection means for the GH95, Sid81, and PV57 isolates after 14 days $18^{\circ} \mathrm{C}$ were $7.1,4.6$, and $4.5 \%$, respectively.

At $18^{\circ} \mathrm{C}$ against two of the isolates ( $\mathrm{Sid} 81$ and $\mathrm{GH} 95$ ), PI3672127 expressed TSR that was significantly less robust than that of the two resistant checks (Table 5), while PI321730 failed to match the TSR of the checks only in response to inoculation with the Sid81 isolate (Table 5). The GH95 isolate differentiated the relative effectiveness of the TSRs of the 20 candidate sources most effectively. Of the 20 TSR candidate sources, 6 (CItr9358, PI225220, PI245399, PI268438, PI268459, and PI367127) expressed less effective resistance than the Wsm1- and Wsm2-bearing resistant checks, whereas the TSRs expressed by the other candidate sources were statistically indistinguishable from the resistant checks (Table 5). The overall infection means for the GH95, Sid81, and PV57 isolates after 21 days at $18^{\circ} \mathrm{C}$ were $19.5,7.4$, and $5.1 \%$, respectively.

The $20^{\circ} \mathrm{C}$ treatment clearly differentiated the relative virulence of the three WSMV isolates (Tables 3, 6, and 7). As early as 7 DPI, a high proportion (83\%) of plants of the Wsm2-bearing RonL resistant check were symptomatic after inoculation with the G95 isolate, whereas the PV57 and Sid81 isolates induced in RonL only low proportions of infected plants (Table 3). Among the 20 candidate TSR sources, the GH95 isolate induced in 5 of them (CItr9358, PI225220, PI245526, PI268459, and PI367127) significantly higher proportions of symptomatic plants than those recorded for the PV57 and Sid81 isolates (Table 3). By 14 DPI, the Sid81 and GH95 isolates had induced symptoms in at least a few plants of all 20 candidate TSR sources as well as for the two TSR checks, KS96HW10-3 and RonL. By contrast, the KS96HW10-3 TSR check and 7 of the 20 TSR candidates were still uniformly free of symptoms at 14 DPI with the PV57 isolate (Table 6). With

Table 5. Percentages of symptomatic wheat plants for different wheat lines in response to mechanical inoculation with three isolates of Wheat streak mosaic virus (WSMV) after 21 days at $18^{\circ} \mathrm{C}^{\mathrm{y}}$

\begin{tabular}{lccc}
\hline & \multicolumn{3}{c}{ WSMV isolate $^{\mathbf{z}}$} \\
\cline { 2 - 4 } Identification number & GH95 & Sid81 & PV57 \\
\hline CItr9358 & $18 \mathrm{~d}$ & $0 \mathrm{e}$ & $4 \mathrm{de}$ \\
PI225220 & $65 \mathrm{~b}$ & $0 \mathrm{e}$ & $0 \mathrm{e}$ \\
PI225222 & $0 \mathrm{e}$ & $0 \mathrm{e}$ & $0 \mathrm{e}$ \\
PI225288 & $0 \mathrm{e}$ & $0 \mathrm{e}$ & $0 \mathrm{e}$ \\
PI243652 & $4 \mathrm{de}$ & $4 \mathrm{de}$ & $0 \mathrm{e}$ \\
PI243753 & $0 \mathrm{e}$ & $0 \mathrm{e}$ & $0 \mathrm{e}$ \\
PI245399 & $12 \mathrm{~d}$ & $0 \mathrm{e}$ & $0 \mathrm{e}$ \\
PI245439 & $4 \mathrm{de}$ & $0 \mathrm{e}$ & $0 \mathrm{e}$ \\
PI245526 & $0 \mathrm{e}$ & $0 \mathrm{e}$ & $0 \mathrm{e}$ \\
PI268438 & $52 \mathrm{bc}$ & $5 \mathrm{de}$ & $13 \mathrm{de}$ \\
PI268459 & $69 \mathrm{~b}$ & $0 \mathrm{e}$ & $0 \mathrm{e}$ \\
PI321730 & $0 \mathrm{e}$ & $25 \mathrm{~d}$ & $0 \mathrm{e}$ \\
PI243639 & $0 \mathrm{e}$ & $0 \mathrm{e}$ & $0 \mathrm{e}$ \\
PI243669 & $4 \mathrm{de}$ & $0 \mathrm{e}$ & $0 \mathrm{e}$ \\
PI245539 & $0 \mathrm{e}$ & $0 \mathrm{e}$ & $0 \mathrm{e}$ \\
PI250041 & $0 \mathrm{e}$ & $0 \mathrm{e}$ & $0 \mathrm{e}$ \\
PI342631 & $8 \mathrm{de}$ & $0 \mathrm{e}$ & $0 \mathrm{e}$ \\
PI366549 & $0 \mathrm{e}$ & $0 \mathrm{e}$ & $0 \mathrm{e}$ \\
PI367127 & $100 \mathrm{a}$ & $33 \mathrm{c}$ & $0 \mathrm{e}$ \\
PI478095 & $4 \mathrm{de}$ & $0 \mathrm{e}$ & $0 \mathrm{e}$ \\
RonL & $9 \mathrm{de}$ & $0 \mathrm{e}$ & $0 \mathrm{e}$ \\
KS96HW10-3 & $0 \mathrm{e}$ & $4 \mathrm{de}$ & $0 \mathrm{e}$ \\
T81 & $100 \mathrm{a}$ & $100 \mathrm{a}$ & $100 \mathrm{a}$ \\
Overall mean & 19.5 & 7.4 & 5.1 \\
\hline
\end{tabular}

y Percentages are means from three experiments and are not arcsine transformed. However, values were arcsine transformed prior to analyses. Total plant numbers of plants for a given accession and virus isolate were 18 to 25 .

${ }^{\mathrm{z}}$ Treatments not having the same letter (within and across columns) in common are significantly different using Fisher's protected least significance difference $(P=0.05)$. The probability associated with the $F$ value was $<0.0001$. the exception of PI321730 inoculated with the Sid81 isolate, candidate TSR sources inoculated with the GH95 isolate had the most infected plants, with proportions of symptomatic plants ranging from 100\% for PI 268438 and PI367127 to 44\% for PI243753. Within this range, there were significant differences among 11 of the candidate TSR lines, whereas RonL and KS96HW10-3 did not differ from the T81 susceptible check.

In the more stringent $20^{\circ} \mathrm{C}$ treatment, three candidate TSR sources (PI225288, PI243753, and PI245439) had significantly smaller infection percentages than the resistant checks and the other TSR candidates (Tables 3, 6, and 7). The responses to Sid81 at 14 DPI showed the greatest range and differentiation of the effectiveness of TSR among the 20 candidates: proportions of symptomatic plants ranged from $100 \%$ for PI367127 to $4 \%$ for PI 243639 and PI250041. Within this range, there were significant differences. PI225220, PI268459, PI321730, and PI367127 were statistically indistinguishable from the T81 susceptible control, whereas the KS96HW10-3 TSR check and 12 of the 20 candidates were indistinguishable from the low proportion (4\%) observed for PI243639. The response to Sid81 at $14 \mathrm{DPI}$ in the $20^{\circ} \mathrm{C}$ regime likewise clearly differentiated the TSRs expressed by Wsml-bearing KS96HW10-3 and Wsm2-bearing RonL (Table 6). The relative mildness of the PV57 isolate is also evident from the results at 14 DPI in the $20^{\circ} \mathrm{C}$ regime. Only one candidate (PI367127), with uniformly symptomatic plants, was indistinguishable from the T81 susceptible check, whereas KS96HW10-3 and 7 of 20 TSR candidates were uniformly symptom free and a further 5 were statistically indistinguishable from this minimal infection level (Table 6). The overall infection means for the GH95, Sid81, and PV57 isolates after 14 days at $20^{\circ} \mathrm{C}$ were $75.6,36.8$, and $17.1 \%$, respectively.

In the $20^{\circ} \mathrm{C}$ regime at $21 \mathrm{DPI}$, depending upon the virus isolate, most but not all TSR candidates had plants with symptoms (Table 7). In response to inoculation with the GH95, Sid81, and PV57

Table 6. Percentages of symptomatic wheat plants for plants for different wheat lines in response to mechanical inoculation with three isolates of Wheat streak mosaic virus (WSMV) after 14 days at $20^{\circ} \mathrm{C}^{\mathrm{y}}$

\begin{tabular}{lccc}
\hline & \multicolumn{3}{c}{ WSMV isolate } \\
\cline { 2 - 4 } Identification number & GH95 & Sid81 & PV57 \\
\hline CItr9358 & $84 \mathrm{a}-\mathrm{g}$ & $32 \mathrm{l}-\mathrm{v}$ & $9 \mathrm{r}-\mathrm{w}$ \\
PI225220 & $95 \mathrm{ab}$ & $76 \mathrm{a}-\mathrm{j}$ & $47 \mathrm{~g}-\mathrm{p}$ \\
PI225222 & $85 \mathrm{a}-\mathrm{e}$ & $39 \mathrm{j}-\mathrm{s}$ & $19 \mathrm{p}-\mathrm{w}$ \\
PI225288 & $50 \mathrm{~h}-\mathrm{q}$ & $13 \mathrm{~s}-\mathrm{w}$ & $13 \mathrm{~s}-\mathrm{w}$ \\
PI243652 & $60 \mathrm{~d}-\mathrm{n}$ & $26 \mathrm{~m}-\mathrm{w}$ & $0 \mathrm{w}$ \\
PI243753 & $44 \mathrm{i}-\mathrm{r}$ & $9 \mathrm{r}-\mathrm{w}$ & $0 \mathrm{w}$ \\
PI245399 & $72 \mathrm{~b}-1$ & $21 \mathrm{~m}-\mathrm{w}$ & $8 \mathrm{~s}-\mathrm{w}$ \\
PI245439 & $50 \mathrm{~g}-\mathrm{p}$ & $22 \mathrm{~m}-\mathrm{w}$ & $0 \mathrm{w}$ \\
PI245526 & $91 \mathrm{a}-\mathrm{c}$ & $22 \mathrm{~m}-\mathrm{w}$ & $4 \mathrm{vw}$ \\
PI268438 & $100 \mathrm{a}$ & $54 \mathrm{e}-\mathrm{n}$ & $8 \mathrm{~s}-\mathrm{w}$ \\
PI268459 & $83 \mathrm{a}-\mathrm{j}$ & $81 \mathrm{a}-\mathrm{h}$ & $13 \mathrm{q}-\mathrm{w}$ \\
PI321730 & $72 \mathrm{a}-\mathrm{i}$ & $76 \mathrm{a}-\mathrm{h}$ & $18 \mathrm{o}-\mathrm{w}$ \\
PI243639 & $62 \mathrm{~b}-\mathrm{l}$ & $4 \mathrm{vw}$ & $9 \mathrm{r}-\mathrm{w}$ \\
PI243669 & $62 \mathrm{~b}-\mathrm{l}$ & $41 \mathrm{i}-\mathrm{r}$ & $5 \mathrm{vw}$ \\
PI245539 & $65 \mathrm{~b}-\mathrm{l}$ & $14 \mathrm{~s}-\mathrm{w}$ & $0 \mathrm{w}$ \\
PI250041 & $56 \mathrm{f}-\mathrm{o}$ & $4 \mathrm{vw}$ & $5 \mathrm{vw}$ \\
PI342631 & $65 \mathrm{~b}-\mathrm{j}$ & $7 \mathrm{r}-\mathrm{w}$ & $0 \mathrm{w}$ \\
PI366549 & $71 \mathrm{~b}-1$ & $18 \mathrm{o}-\mathrm{w}$ & $0 \mathrm{w}$ \\
PI367127 & $100 \mathrm{a}$ & $100 \mathrm{a}$ & $100 \mathrm{a}$ \\
PI478095 & $87 \mathrm{a}-\mathrm{d}$ & $9 \mathrm{r}-\mathrm{w}$ & $0 \mathrm{w}$ \\
RonL & $100 \mathrm{a}$ & $70 \mathrm{~b}-\mathrm{k}$ & $36 \mathrm{k}-\mathrm{u}$ \\
KS96HW10-3 & $85 \mathrm{a}-\mathrm{e}$ & $10 \mathrm{r}-\mathrm{w}$ & $0 \mathrm{w}$ \\
T81 & $100 \mathrm{a}$ & $100 \mathrm{a}$ & $100 \mathrm{a}$ \\
Overall mean & 75.6 & 36.8 & 17.1 \\
\hline & & & \\
\hline
\end{tabular}

y Percentages are means from three experiments and are not arcsine transformed. However, values were arcsine transformed prior to analyses. Total plant numbers of plants for a given accession and virus isolate were 19 to 25 .

z Treatments not having the same letter (within and across columns) in common are significantly different using Fisher's protected least significance difference $(P=0.05)$. The probability associated with the $F$ value was $<0.0001$. 
virus isolates there were 1,17 , and 20 candidate TSR sources, respectively, that differed significantly from the uniform infection displayed by the T81 susceptible check (Table 7). The overall infection means for the GH95, Sid81, and PV57 isolates after 21 days at $20^{\circ} \mathrm{C}$ were $95.0,58.6$, and $24.8 \%$, respectively.

\section{Discussion}

The responses of the wheat lines CO960293, CO960333, and KS03HW12 to the Sid81 isolate of WSMV identified them as expressing TSR at $18^{\circ} \mathrm{C}$, resistance which protected these lines against yield losses from WSMV infection under field conditions (25-27; D. L. Seifers unpublished). Motivated by finding new sources of WSMV resistance in pure wheat backgrounds, similar protocols were applied here, using responses to inoculation with the Sid81 isolate to identify 20 new candidate sources of TSR among 2,429 tested accessions from the National Small Grains Collection.

These 20 accessions are not represented in the pedigrees of RonL (27) or the lines KS06HW79 (D. L. Seifers, unpublished), KS03HW12 (26), or KS96HW10-3 (25), indicating that the resistance they express cannot necessarily be attributed to the same genes. By inoculating with three distinct isolates of WSMV in constant temperature regimes of 18 and $20^{\circ} \mathrm{C}$, differences in expression of resistance among the 20 TSR candidates were identified (Tables 5 and 7), which will be important when selecting lines as sources of WSMV resistance in breeding programs.

Previously, the GH95 isolate of WSMV was shown to be more virulent in a regime of $18^{\circ} \mathrm{C}$, because it overcame TSR expressed by certain sources of resistance that had protected against infection with Sid81 and other isolates (D. L. Seifers, unpublished). The findings presented here confirm and extend these observations. At $21 \mathrm{DPI}$ in the $18^{\circ} \mathrm{C}$ regime, the GH95 isolate differentiated the effectiveness of candidate TSR sources: four of the candidates had significantly higher numbers of infected plants than the RonL and KS96HW10-3 resistant checks yet significantly lower than the T81 susceptible check (Table 5), whereas other candidate TSR sources resisted infections as effectively as the Wsml-and Wsm2-bearing resistant checks.

Until the TSR expressed in CO960293 was discovered, the only extensively characterized genetic source of resistance to WSMV introgressed into wheat was the one derived from $T$. intermedium (25). Designated as Wsml and deployed in chromosome substitution and translocation lines (such as KS96HW10-3 and Mace), it protects against losses from WSMV infection at the cost of the greater selection effort needed to address the "linkage drag" associated with the alien chromatin $(6,25)$. The discovery of TSR in the elite wheat line CO960293 showed that resistance to WSMV could be effectively expressed in germplasm derived from susceptible parents entirely free of alien chromatin (27). This discovery also suggested the possibility that genetic resistance to WSMV might not be rare in the wheat germplasm pool if search efforts were extended to discover similar TSR among the descendants of other sets of susceptible wheat parents or progenitors $(3,4,7)$. The success of these relatively small-scale efforts encouraged us to cast the net more widely and take advantage of the ability of distinct WSMV isolates to reveal useful differences in TSR profiles among candidates identified by an initial screen with a single isolate.

Such differences are illustrated by the performance of the nine TSR candidates that originated from Afghanistan (Table 2). In response to inoculation with the $\mathrm{GH} 95$ isolate in the $18^{\circ} \mathrm{C}$ regime, six of the nine (PI245399, PI245439, PI245526, PI321730, PI245539, and PI366549) remained uniformly (or nearly uniformly) asymptomatic, expressing resistance indistinguishable from the Wsm1-bearing (KS96HW10-3) and Wsm2-bearing (RonL) resistant checks (Table 5). The other three (PI268438, PI268459, and PI367127) differed in having significant proportions of symptomatic plants, and one of these (PI367127) had significantly more symptomatic plants than any other TSR candidate as early as 14 DPI (Tables 4 and 5). These clear differences in expression of resistance may be due to differences in genes or gene al- leles for resistance but there is currently no information about genetic resistance to WSMV in accessions from Afghanistan or Pakistan.

Differences in levels of expressed resistance were also observed among the nine TSR candidates of Iranian origin (Table 2). In response to inoculation with the GH95 isolate, eight of these lines were indistinguishable from the resistant checks, while PI225220 had significantly more plants with symptoms as early as 14 DPI (Tables 4 and 5). Varying levels of resistance in Iranian wheat landraces (inoculated with an Iranian isolate of WSMV under greenhouse conditions) have been reported (18) but the data are not yet available to determine whether any of these sources of resistance are the same as those identified in this study (18). Although an argument can be made that the likeliest area to yield abundant TSR candidates is the region where wheat originated, now thought to be near the Caspian Sea in Iran (20), searches for candidate TSR sources should not be geographically limited. The source of the CItr9358 candidate TSR is Finland (www.ars-grin.gov), which means it has been selected for adaptation to environments remote from the Caspian Sea or the Fertile Crescent. Nonetheless, this candidate TSR was one of the most effective discovered in this study.

We have identified 20 TSR candidate sources from 2,429 accessions from the National Small Grains Collection. Depending upon the isolate of WSMV used for inoculation, these TSRs prevent symptom development at least up to 21 days in growth chamber experiments conducted at $18^{\circ} \mathrm{C}$. Nine of the accessions were from Afghanistan, one from Finland, nine from Iran, and one from Pakistan. Our results show that simple screening will reveal TSR lines in existing wheat germplasm collections, warranting more extensive screening encompassing larger or other, more specialized collections. These 20 new sources of resistance should prove a useful resource to wheat breeding programs seeking to reduce losses from WSMV.

Table 7. Percentages of symptomatic wheat plants from plants for different wheat lines in response to mechanical inoculation with three isolates of Wheat streak mosaic virus (WSMV) after 21 days at $20^{\circ} \mathrm{C}^{\mathrm{y}}$

\begin{tabular}{lccc}
\hline & \multicolumn{3}{c}{ WSMV isolate $^{\mathbf{z}}$} \\
\cline { 2 - 4 } Identification number & GH95 & Sid81 & PV57 \\
\hline CItr9358 & $100 \mathrm{a}$ & $62 \mathrm{c}-1$ & $19 \mathrm{~m}-\mathrm{s}$ \\
PI225220 & $100 \mathrm{a}$ & $88 \mathrm{a}-\mathrm{d}$ & $63 \mathrm{~b}-\mathrm{k}$ \\
PI225222 & $90 \mathrm{a}-\mathrm{c}$ & $55 \mathrm{~g}-1$ & $38 \mathrm{l}-\mathrm{s}$ \\
PI225288 & $90 \mathrm{a}-\mathrm{c}$ & $32 \mathrm{l}-\mathrm{s}$ & $18 \mathrm{o}-\mathrm{t}$ \\
PI243652 & $100 \mathrm{a}$ & $57 \mathrm{~h}-\mathrm{m}$ & $14 \mathrm{p}-\mathrm{t}$ \\
PI243753 & $92 \mathrm{ab}$ & $43 \mathrm{i}-\mathrm{n}$ & $0 \mathrm{t}$ \\
PI245399 & $92 \mathrm{ab}$ & $50 \mathrm{j}-\mathrm{n}$ & $20 \mathrm{n}-\mathrm{t}$ \\
PI245439 & $87 \mathrm{a}-\mathrm{g}$ & $32 \mathrm{l}-\mathrm{r}$ & $0 \mathrm{t}$ \\
PI245526 & $100 \mathrm{a}$ & $59 \mathrm{f}-\mathrm{l}$ & $16 \mathrm{o}-\mathrm{t}$ \\
PI268438 & $100 \mathrm{a}$ & $68 \mathrm{~b}-\mathrm{k}$ & $25 \mathrm{~m}-\mathrm{s}$ \\
PI268459 & $92 \mathrm{ab}$ & $81 \mathrm{a}-\mathrm{i}$ & $35 \mathrm{l}-\mathrm{q}$ \\
PI321730 & $94 \mathrm{ab}$ & $88 \mathrm{ab}$ & $45 \mathrm{j}-\mathrm{o}$ \\
PI243639 & $91 \mathrm{a}-\mathrm{e}$ & $67 \mathrm{~b}-\mathrm{k}$ & $9 \mathrm{q}-\mathrm{t}$ \\
PI243669 & $100 \mathrm{a}$ & $64 \mathrm{~d}-\mathrm{l}$ & $10 \mathrm{r}-\mathrm{t}$ \\
PI245539 & $95 \mathrm{ab}$ & $52 \mathrm{e}-1$ & $0 \mathrm{t}$ \\
PI250041 & $82 \mathrm{~b}-\mathrm{j}$ & $19 \mathrm{n}-\mathrm{t}$ & $4 \mathrm{st}$ \\
PI342631 & $100 \mathrm{a}$ & $36 \mathrm{j}-\mathrm{p}$ & $6 \mathrm{st}$ \\
PI366549 & $95 \mathrm{ab}$ & $56 \mathrm{~g}-\mathrm{m}$ & $0 \mathrm{t}$ \\
PI367127 & $100 \mathrm{a}$ & $100 \mathrm{a}$ & $100 \mathrm{a}$ \\
PI478095 & $100 \mathrm{a}$ & $40 \mathrm{k}-\mathrm{p}$ & $4 \mathrm{st}$ \\
RonL & $100 \mathrm{a}$ & $85 \mathrm{a}-\mathrm{d}$ & $40 \mathrm{k}-\mathrm{p}$ \\
KS96HW10-3 & $86 \mathrm{a}-\mathrm{h}$ & $16 \mathrm{p}-\mathrm{t}$ & $5 \mathrm{st}$ \\
T81 & $100 \mathrm{a}$ & $100 \mathrm{a}$ & $100 \mathrm{a}$ \\
Overall mean & 95.0 & 58.6 & 24.8 \\
\hline
\end{tabular}

${ }^{y}$ Percentages are means from three experiments and are not arcsine transformed. However, values were arcsine transformed prior to analyses. Total plant numbers of plants for a given accession and virus isolate were 18 to 25 .

${ }^{\mathrm{z}}$ Treatments not having the same letter (within and across columns) in common are significantly different using Fisher's protected least significance difference $(P=0.05)$. The probability associated with the $F$ value was $<0.0001$. 


\section{Acknowledgments}

This research was funded, in part, by a grant from the Kansas Wheat Commission. We thank J. Ackerman for his valuable assistance in virus propagation, planting, and inoculation of plants in the different experiments during this study; and C. Seaman for his assistance in data analyses.

\section{Literature Cited}

1. Dwyer, G. I., Gibbs, M. J., Gibbs, A. J., and Jones, R. A. C. 2007. Wheat streak mosaic virus in Australia: relationship to isolates from the Pacific Northwest of the USA and its dispersion via seed transmission. Plant Dis. 91:164-170.

2. Edwards, M. C., and McMullen, M. P. 1988. Variation in tolerance to wheat streak mosaic virus among cultivars of hard red spring wheat. Plant Dis. 72:705-707.

3. Fahim, M., Larkin, P., Haber, S., Shorter, S., Lonegram, P., and Rosewarne, G. 2012. Effectiveness of three potential sources of resistance in wheat against Wheat streak mosaic virus under field conditions. Australas. Plant Pathol. 41:301-309.

4. Fahim, M., Mechanicos, A., Ayala-Navarrete, L., Haber, S., and Larkin, P. J. 2012. Resistance to Wheat streak mosaic virus-a survey of resources and development of molecular markers. Plant Pathol. 61:425-440.

5. Friebe, B., Mukai, Y., Dhaliwal, H. S., Martin, T. J., and Gill, B. S. 1991. Identification of alien chromatin specifying resistance to wheat streak mosaic virus and greenbug in wheat germplasm by C-banding and in situ hybridization. Theor. Appl. Genet. 81:381-389.

6. Graybosch, R. A., Peterson, C. J., Baenziger, P. S., Baltensperger, D. D., Nelson, L. A., Jin, Y., Kolmer, J., Seabourn, B., French, R., Hein, G., Martin, T. J., Beecher, B. Schwarzacher, T., and Heslop-Harrison, P. 2009. Registration of "Mace" hard red winter wheat. J. Plant Regist. 3:51-56.

7. Haber, S., Gilbert, J., Seifers, D. L., and Comeau, A. 2011. Epigenetics serves genetics: Fusarium head blight (FHB) resistance in elite wheat germplasm. Am. J. Plant Sci. Biotechnol. 5:95-100.

8. Haley, S. D., Johnson, J. J., Peairs, F. B., Stromberger, J., Heaton, E., Seifert, S., Kottke, R., Rudolph, J., Martin, T., Bai, G., Chen, X., Bowden, R. L., Jin, Y., Kolmer, J. A., Seifers, D., Chen, M., and Seabourn, B. W. 2011. Registration of 'Snowmass' wheat. J. Plant Regul. 5:878-90.

9. Haley, S. D., Martin, T. J., Quick, J. S., Seifers, D. L., Stromberger, J. A.., Gill, B. S., and Freibe, B. 2002. Registration of C0960293-2 wheat germplasm resistant to Wheat streak mosaic virus and Russian wheat aphid. Crop Sci. 42:1381-1382.

10. Harvey, T. L., Seifers, D. L., Martin, T. J., Brown-Guedira, G., and Gill, B. S. 1999. Survival of wheat curl mites on different sources of resistance in wheat. Crop Sci. 39:1887-1889.

11. Jones, R. A. C., Coutts, B. A., Mackie, A. E., and Dwyer, G. I. 2005. Seed transmission of Wheat streak mosaic virus shown unequivocally in wheat. Plant Dis. 89:1048-1050.

12. Lanoiselet, V. M., Hind-Lanoiselet, T. L., and Murray, G. M. 2008. Studies on the seed transmission of wheat streak mosaic virus. Australas. Plant Pathol. 37:584-588.

13. Lengkeck, V. H. 1979. Wheat Virus Diseases in Southwestern Kansas. Coop. Ext. Rep. Kans. State Univ. Manhattan.

14. Little, T. M., and Hills, R. J. 1978. Transformation. Pages 139-165 in: Agricultural Experimentation: Design and Analysis. T. M. Little and F. J. Hills, eds. John Wiley \& Sons, New York.

15. Liu, W., Seifers, D. L., Qi, L. L., Friebe, B., and Gill, B. S. 2011. A compensating wheat-Thinopyrum intermedium Robertsonian translocation conferring resistance to Wheat streak mosaic virus and Triticum mosaic virus. Crop Sci. 51:2382-2390.

16. Lu, H. J., Kottke, R., Devkota, R., St. Amand, P., Bernardo, A., Bai, G., Byrne, P., Martin, T. J., Haley, S. D., and Rudd, J. 2012. Consensus mapping and identification of markers for marker-assisted selection of Wsm2 in wheat Crop Sci. 52:720-728.

17. Lu, H. J., Price, J., Devkota, R., Rush, C., and Rudd, J. 2011. A dominant gene for resistance to Wheat streak mosaic virus in winter wheat line CO960293-2. Crop Sci. 51:5-12.

18. Masumi, M., Yassaie, M., Zare, A., and Izadpanah, K. 2005. Fertile Crescent is the epicenter of Wheat streak mosaic virus. In: Proc. 10th Conf. Viral Dis. Gramineae Eur. Louvain-la-Neuve, Belgium.

19. McKinney H. H., and Sando, W. J. 1951. Susceptibility and resistance to the wheat streak-mosaic virus in the genera Triticum, Agropyron, Secale, and certain hybrids. Plant Dis. Rep. 35:476-479.

20. Nesbitt M., and Samuel, D. 1998. Wheat domestication: Archaeobotanical evidence. Science 279:1431.

21. Schiffer, M., Umina, P., Carew, M., Hoffmann, A., Rodoni, B., and Miller, A. 2009. The distribution of wheat curl mite (Aceria tosichella) lineages in Australia and their potential to transmit Wheat streak mosaic virus. Ann. Appl. Biol. 155:371-379.

22. Seifers, D. L. 1992. Partial characterization of a Colorado isolate of Agropyron mosaic virus. Plant Dis. 76:564-569.

23. Seifers, D. L., Harvey, T. L., Martin, T. J., and Jensen, S. G. 1997. Identification of the wheat curl mite as the vector of the High Plains virus of corn and wheat. Plant Dis. 81:1161-1166.

24. Seifers D. L., Martin T. J., Harvey T. J., Fellers J. P., and Michaud J. P. 2009. Identification of the wheat curl mite as the vector of Triticum mosaic virus. Plant Dis. 93:25-29.

25. Seifers, D. L., Martin, T. J., Harvey, T. L., and Gill, B. S. 1995. Temperature sensitivity and efficacy of wheat streak mosaic virus resistance derived from Agropyron intermedium. Plant Dis. 79:1104-1106.

26. Seifers, D. L., Martin, T. J., Harvey, T. L., and Haber, S. 2007. Temperaturesensitive Wheat streak mosaic virus resistance identified in KS03HW-12 wheat. Plant Dis. 91:1029-1033.

27. Seifers, D. L., Martin, T. J., Harvey, T. L., Haber, S., and Haley, S. D. 2006. Temperature sensitivity and efficacy of Wheat streak mosaic virus resistance derived from C0960293 wheat. Plant Dis. 90:623-628.

28. Sim, T., IV, Willis, W. G., and Eversmeyer, M. G. 1988. Kansas plant disease survey. Plant Dis. 72:832-836.

29. Slykhuis, J. T. 1955. Aceria tulipae Keifer (Acrina: Eriophyidae) in relation to the spread of wheat streak mosaic. Phytopathology 45:116-128.

30. Stenger, D. C., Hall, J. S., Choi, I.-R., and French, R. 1998. Phylogenetic relationships within the family Potyviridae: Wheat streak mosaic virus and Brome streak mosaic virus are not members of the genus Rymovirus. Phytopathology 88:782-787.

31. Stenger, D. C., Seifers, D. L., and French, R. 2002. Patterns of polymorphism in Wheat streak mosaic virus: Sequence space explored by a clade of closely related viral genotypes rivals that between the most divergent strains. Virology 302:58-70.

32. Willis, W. G. 1981. The 1981 Wheat Streak Mosaic Epidemic in Kansas. Coop. Ext. Rep. Kans. State Univ. Manhattan. 